\title{
Pollination success in monochromic yellow populations of the rewardless orchid Dactylorhiza sambucina
}

\author{
M. Kropf ${ }^{1}$ and S. S. Renner ${ }^{2}$ \\ ${ }^{1}$ Institut für Botanik, BOKU - University of Natural Resources and Applied Life Sciences, Vienna, \\ Austria \\ ${ }^{2}$ Systematische Botanik, Ludwig-Maximilians University, Munich, Germany
}

Received October 10, 2004; accepted March 21, 2005

Published online: July 15, 2005

(C) Springer-Verlag 2005

\begin{abstract}
Dactylorhiza sambucina is a European terrestrial orchid that lacks a pollinator reward. Throughout most of its range, populations contain yellow- and purple-flowering individuals, but in western Germany, monomorphic yellow populations predominate. As elsewhere, bumblebee queens are the most important pollinators in these populations, and mean fruit set over two years was $19 \%$, well within the range reported from dimorphic populations. Multivariate analyses of plant and population traits, including plant height, leaf number, flower number and density on the spikes, flowering population density, and nearest neighbor distance, showed that only individual plant height and population density had a unique positive effect on pollen export; female function was unrelated to height or population density. The positive effects of dense spacing of flowering conspecifics and tall size appear due to greater visual attractiveness. Good visual exposure may also explain that flowers higher up on the spikes, in spite of opening late in the season, had higher male reproductive success than early flowers.
\end{abstract}

Key words: Bumblebees, Dactylorhiza sambucina, flower color dimorphism, monochromic populations, pollination success, rewardless flowers.
Dactylorhiza sambucina is a terrestrial European orchid that lacks any pollinator rewards. Even so, the nectarless floral spurs are probed by foraging bumblebees, which transfer the pollinia at a rate high enough for the species to persist in abundant populations throughout its range (Delpino 1874, Skottsberg 1907, Ziegenspeck 1936, Nilsson 1980, Pettersson and Nilsson 1983, Vogel 1993, Vöth 1999). Dactylorhiza sambucina has attracted much attention from pollination ecologists through its flower color dimorphism, with yellow- and purpleflowering individuals co-occurring at apparently stable ratios in most of the species' range (see Gigord et al. 2001, 2002). Using synthetic arrays of potted D. sambucina with differing frequencies of yellow- and purple-flowering individuals, Gigord et al. (2001) found that pollinia export, receipt, and fruit set were highest in mixed populations and that for fruit set, morph frequencies of $61 \%$ yellow and $39 \%$ purple individuals represented an equilibrium maintained by negative frequencydependent selection. Pollinators, mainly queens that have found the flowers devoid of nectar will switch between flower color morphs, 
thus over-visit the rare morph, and as a result, the relative fitness of the rare phenotype will be increased (Gigord et al. 2001). The small, but consistent, bias in favor of the yellow morph found in Gigord et al.'s experiments was explained as possibly due to pollinator preference for the yellow color of the orchid. By contrast, Jersáková et al. (in press) in 22 Czech populations of $D$. sambucina found no relationship between the reproductive success of the purple and yellow morph and their relative frequencies, leading them to doubt the maintenance of the color-dimorphism by frequencydependent selection under natural conditions. In addition, different from the situation in Gigord et al.'s study plots in France, most of the Czech populations showed a huge bias towards the purple form. A study of yellowdominated populations from southern Italy raises further doubts about the maintenance of the color dimorphism by pollinator discrimination (Pellegrino et al. 2005)

Different from the situation found throughout much of its range, populations of D. sambucina in Western Germany consist almost exclusively of yellow-flowered individuals. In the Rhineland-Palatinate, the purplecolored flower morph is known to have occurred (at low frequencies) in the 1840s, but is now extremely rare (Schultz 1846, Künkele and Baumann 1998). Between 1994 and 2003, 17 of 19 populations monitored. by M.K. in the Rhineland-Palatinate contained no purple-flowering individuals, while two contained one or two purple-flowering plants. The purple-bias in Czech populations of $D$. sambucina (Jersáková et al., in press), nearabsence of purple plants in the center of the species' European range, and possible yellow bias in southern France (Gigord et al. 2001) raises the question of which environmental factors may select on morph ratios. Of course, the loss of a morph could be entirely due to genetic drift in small populations.

Here we report on pollinia export, receipt, and fruit set in two years, 1995 and 2003, in naturally yellow Rhineland-Palatinate populations of D. sambucina and then compare our results with fruit sets reported from dimorphic populations. Following-up on findings in other rewardless orchids (e.g. Fritz and Nilsson 1995, Sabat and Ackerman 1996), we focus on effects on pollination success of nearest flowering neighbor distances, density of flowering conspecifics, and flower appearance early or late in the season. It had been hypothesized that $D$. sambucina is mostly pollinated by naïve bees and not by more experienced ones (Nilsson 1980) and that plants' reproductive success decreases over the flowering season because bees learn to avoid them (Vogel 1993). We therefore expected that flowers high up on the spikes, which open later than those near the spike base, would have lower male or female success than early-opening flowers. However, pollination success of flowers at different positions along the spike is bound to simultaneously depend on overall plant height, leaf number (a proxy for plant vigor), and population density, and we therefore relied on multivariate analyses to try and identify parameters with significant unique effects.

\section{Material and methods}

Study species. Dactylorhiza sambucina (L.) Soò occurs throughout the Mediterranean, central Europe, and into southern Scandinavia, commonly on rich soils, but sometimes also on siliceous soils as in our study area (Fig. 1). It has basal rosettes and flowers borne spirally on un-branched terminal inflorescences. The flowers' labellum (lip) provides a landing place for bees and bears a basal $10-15 \mathrm{~mm}$ long empty spur. Each of the pollen packages (pollinia) formed by the content of entire pollen sacs is attached via a short stem to a sticky surface (viscidium) that serves to attach the packages to pollinators, and the unit of pollen export therefore is one pollinium. However, pollinia are not deposited on stigmas as entire packages; instead, clusters of pollen grains (massulae) remain on the sticky and concave stigmas of the first couple of flowers visited by the pollinator. A relatively short bending time (the time it takes for a pollinium's stem to bend, such that it can come in contact with a stigma) in $D$. sambucina allows successful 


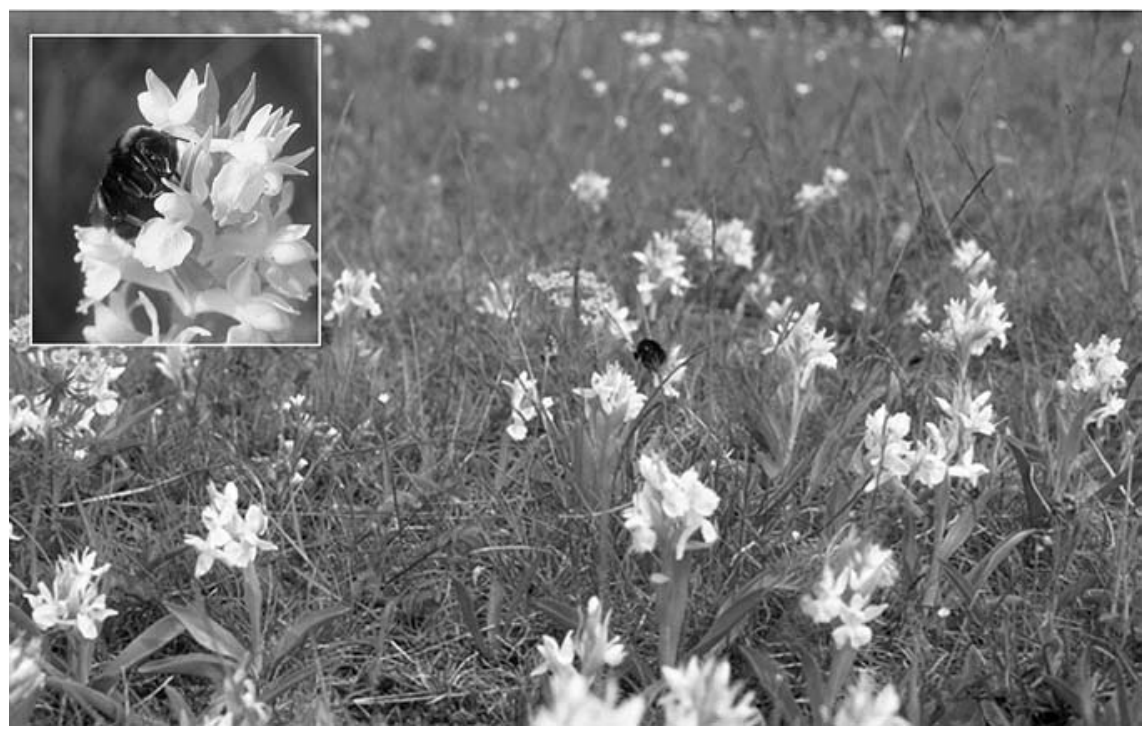

Fig. 1. A dense patch of monochromic yellow Elderflower Orchids, Dactylorhiza sambucina (L.) Soò, within the population Haarberg in Rhineland-Palatinate (Germany). The inset shows a bumblebee Bombus lucorum L. queen as effective pollinator of D. sambucina (photos M. Kropf)

pollination shortly after a pollinium's viscidium has become attached to a pollinator.

Ultraviolett reflectance of yellow flowers in the study area was assessed by monochrome photography with and without a UV filter (Schott UG1 filter, Mainz, Germany, $3 \mathrm{~mm}$ thickness). Spectral reflectances of the purple and yellow morphs of $D$. sambucina were measured in the Hohe Tauern National Park (Austria) at $2300 \mathrm{~m}$ a.s.l. because our study area only contained the yellow morph. There is no reason to suspect differences between the yellow morph spectra at different sites (A. Gumbert, personal communication, 2004). Measurements were made between 320 and $700 \mathrm{~nm}$ with a flash photometer (Groebel SR01, Bensheim, Germany, resolution of $1 \mathrm{~nm}$ ).

Study sites. Populations of D. sambucina were studied near Berlachsberg, Bremroth, and Haarberg (Fig. 2) in the Rheinhessische Schweiz region of the Rhineland-Palatinate (Germany). Each of the three sites had one large population, and Bremroth in addition had an eastern population of four individuals and a western population of eight. Further localities in the same general area, Auf dem Bäder, Dämmerberg, and the nature reserve Haarberg, were added in the second year (Fig. 2). Descriptions of the meadow communities found on the acidic, nutrient-poor siliceous hilltops characteristic of the sites can be found in Korneck (1974) and Kropf (1995). At the study sites, no other orchid species flowered simultaneously with D. sambucina, and the most common nectar- providing species were Potentilla tabernaemontani, Pulsatilla vulgaris, Senecio vernalis, and Taraxacum sect. Erythrosperma.

Pollinator observations, breeding experiments, and male and female pollination success. Pollinator behavior was studied (mainly near Bremroth and Haarberg, during alternating visits) during 26 days, usually from 9 a.m. to 5 p.m., between 9 April and 11 May 1995. For bee identification and monitoring of pollinia transport, we caught visitors that were leaving flowers. We also counted the flowers visited by any one bee. In a few cases, bees could be identified without catching them. In addition, 100 flowers in central positions along the inflorescence on some 40 individuals were (1) emasculated and bagged to test for agamospermy, (2) bagged to test for spontaneous selfing, (3) emasculated, pollinated with pollen from a flower on the same individual, and then bagged, or (4) emasculated and pollinated with pollen from another individual. These bagging experiments were carried out in a subpopulation at the location Berlachsberg (Fig. 2).

For 41 individuals at Haarberg, 19 at Berlachsberg, 72 at Bremroth, and 12 in the two small Bremroth populations (Fig. 2), we quantified plant height $(\mathrm{cm})$, number of leaves, inflorescence length $(\mathrm{cm})$, number and density of flowers on the inflorescence, distance $(\mathrm{cm})$ to the nearest flowering conspecific ('neighbor distance'), and number of co-flowering $D$. sambucina within a 1-m-radius ('neighbor density'). In these 144 individuals, we also monitored number and sequence of pollinia export, receipt, and fruit set in order to quantify 


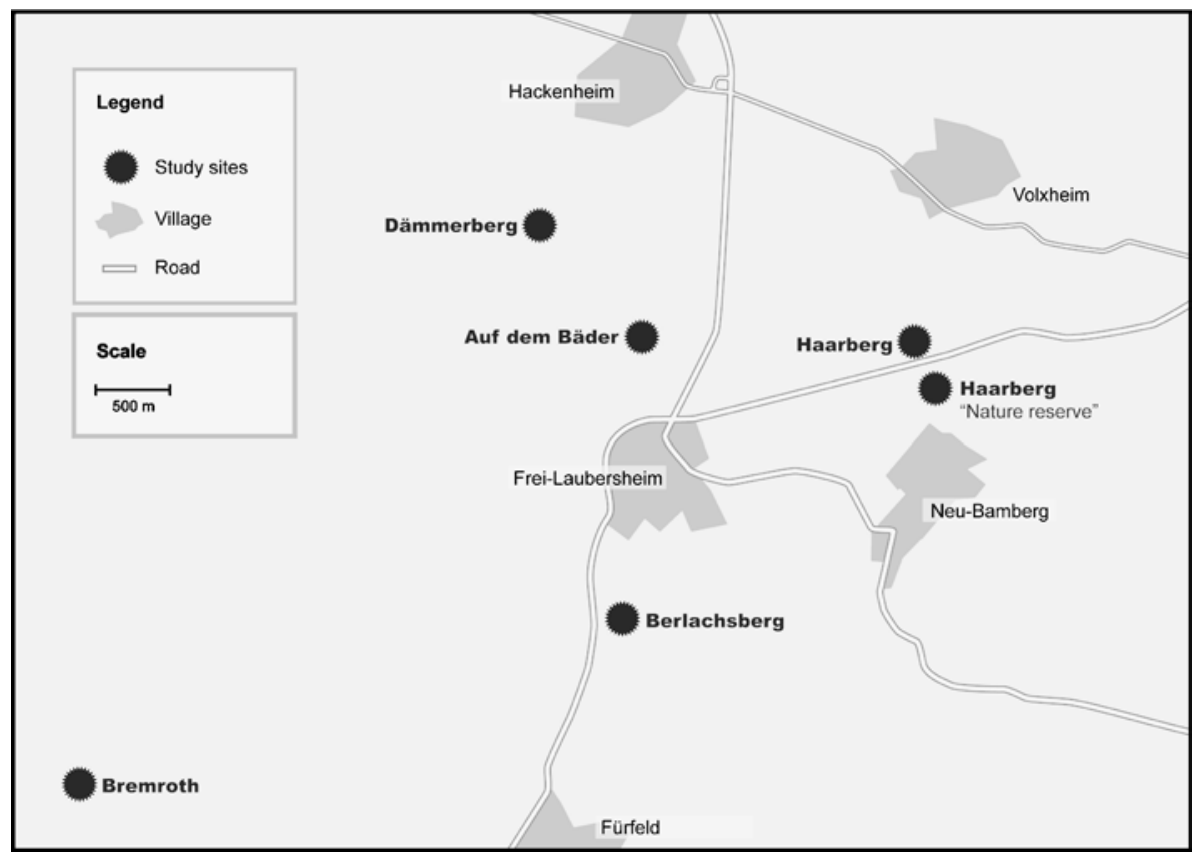

Fig. 2. Geographical locations of the six Dactylorhiza sambucina populations in the Rheinhessische Schweiz region of the Rhineland-Palatinate (Germany) represented in this study

effects of individual traits and flowering conspecifics on pollination success. For the comparison of position-dependent pollination success we utilised the temporal sequence of flowers opening along the inflorescences (starting at the bottom) by defining two groups: i) flower positions $1-9$ (positions below the average flower number; Table 3), and ii) flower positions 10-25 (positions above the average flower number). We calculated mean fruit set and mean pollinia export for each flower position, and compared differences between the two flower position groups running a two-sample randomization test with 10000 permutations (program RT, version 2.1; Manly 1991) for significance testing. In the second year, we monitored fruit set in 210 individuals at the same populations plus three additional ones (Fig. 2; Table 4) to obtain data comparable with fruit sets reported from other deceptive orchid species (Neiland and Wilcock 1998). Male pollination success was calculated by dividing the number of a plant's pollinia removed by those available and female pollination success

Table 1. Dactylorhiza sambucina pollinators in the Rhineland Palatinate, Germany. Bees that also visited nectar-providing co-flowering Lamium purpureum are marked with an asterisk

\begin{tabular}{llll}
\hline $\begin{array}{l}\text { Bumblebee and } \\
\text { cuckoobee species }\end{array}$ & $\begin{array}{l}\text { Body size } \\
\text { of queens } \\
\text { (Hagen 1994) }\end{array}$ & $\begin{array}{l}\text { Proportion of } \\
\text { all 27 direct } \\
\text { pollinator } \\
\text { observations }\end{array}$ & $\begin{array}{l}\text { Proportion of } \\
\text { all 17 pollinia } \\
\text { found on } 9 \text { bees }\end{array}$ \\
\hline $\begin{array}{l}\text { Bombus lapidarius L.* } \\
\text { Bombus lucorum L.* }\end{array}$ & $20-22 \mathrm{~mm}$ & $37 \%$ & $0 \%$ \\
$\begin{array}{l}\text { Bombus soroeensis Fab. } \\
\text { Bombus terrestris L. }\end{array}$ & $18-21 \mathrm{~mm}$ & $30 \%$ & $35 \%$ (3 bees) \\
$\begin{array}{l}\text { Bombus sylvarum L. } \\
\text { Psithyrus vestalis }\end{array}$ & $15-17 \mathrm{~mm}$ & $11 \%$ & $29 \%(2$ bees) \\
$\begin{array}{l}\text { Geoff. in Fourcroy } \\
\text { Psithyrus barbutellus } \text { Kirby }\end{array}$ & $16-23 \mathrm{~mm}$ & $7 \%$ & $18 \%$ (2 bees) \\
\hline
\end{tabular}



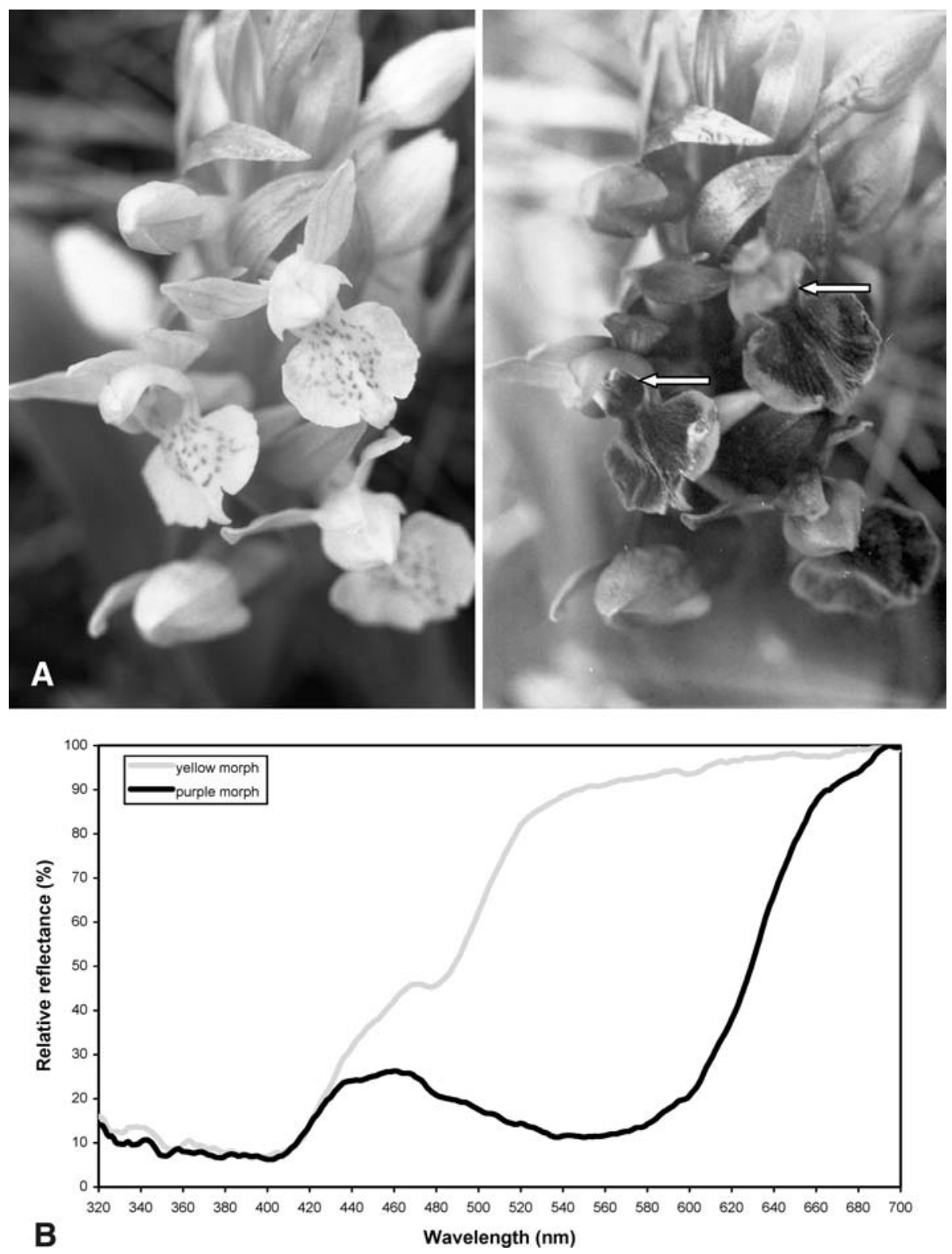

Fig. 3. Dactylorhiza sambucina flower reflectance. A Flowers photographed with (right) and without an ultraviolet (UV) filter. Dark parts absorb UV, while light parts reflect it. The light margin of the lip frames a landing place for bees and dark wedges (arrows) mark the entrance to the spur (photos M. Kropf). B Spectral reflectance of the flowers' lower lips in the purple and yellow morphs (measurements by A. Gumbert and J. Kunze)

by dividing the number of pollen depositions or subsequent fruit set by the number of available flowers. A plant's functional femaleness, $G_{i}$, was calculated following Lloyd (1980) as $\mathrm{G}_{\mathrm{i}}=\mathrm{f}_{\mathrm{i}} /\left(\mathrm{f}_{\mathrm{i}}+\right.$ $\mathrm{m}_{\mathrm{i}} E$ ), where $\mathrm{f}_{\mathrm{i}}$ is the number of fruits, $\mathrm{m}_{\mathrm{i}}$ the number of pollinia removed, and $E$ an equivalence factor calculated as the sum of fruits matured in a population divided by the sum of pollinia removed. Fruit set was ascertained about five weeks after main flowering had ended, when swelling capsules could easily be counted for all previously marked plant individuals.

All measures of male and female pollination success were expressed as fractions and arcsine- 
Table 2. Results of pollination experiments on Dactylorhiza sambucina at the Berlachsberg location

\begin{tabular}{|c|c|c|c|}
\hline & $\begin{array}{l}\text { Emasculation performed / } \\
\text { bagging performed }\end{array}$ & $\begin{array}{l}\text { Numbers of treated } \\
\text { flowers / individuals }\end{array}$ & $\begin{array}{l}\text { Fruit set (percent } \\
\text { of treated flowers) }\end{array}$ \\
\hline Agamospermy & yes/yes & $30 / 12$ & 0 \\
\hline Spontaneous selfing & no/yes & $20 / 8$ & 0 \\
\hline $\begin{array}{l}\text { Experimental selfing } \\
\text { (including geitonogamy) }\end{array}$ & yes/yes & $35 / 15$ & $26(74.3)$ \\
\hline Experimental outcrossing & yes/no & $15 / 7$ & $11(73.3)$ \\
\hline
\end{tabular}

Table 3. Parameters describing individuals, male and female reproductive success, and populations of Dactylorhiza sambucina

\begin{tabular}{llllllc}
\hline & $N$ & $\mathrm{n} *$ & Mean & $\mathrm{S}_{x}$ & Min. & Max. \\
\hline Plant height $(\mathrm{cm})$ & 144 & $\mathrm{n} / \mathrm{a}$ & 16.29 & 4.88 & 7.0 & 40.0 \\
Spike length (cm) & 144 & $\mathrm{n} / \mathrm{a}$ & 4.42 & 1.23 & 2.0 & 10.0 \\
Number of flowers & 144 & $\mathrm{n} / \mathrm{a}$ & 9.56 & 4.71 & 1 & 27 \\
Number of leaves & 144 & $\mathrm{n} / \mathrm{a}$ & 5.35 & 0.98 & 3 & 9 \\
Fruit set (1 $1^{\text {st }}$ year) & 144 & 101 & 0.235 & 0.019 & 0.0 & 1.0 \\
Fruit set (2 $2^{\text {nd }}$ year) & 210 & 115 & 0.158 & 0.011 & 0.0 & 0.7 \\
Pollinia export & 144 & 130 & 0.493 & 0.023 & 0.0 & 1.0 \\
Pollen receipt & 144 & 99 & 0.214 & 0.017 & 0.0 & 1.0 \\
Neighbor distance $(\mathrm{cm})$ & 144 & $\mathrm{n} / \mathrm{a}$ & 45.0 & 92.19 & 2.0 & 1000 \\
Neighbor density & 144 & n/a & 6.44 & 4.92 & 0 & 34 \\
\hline
\end{tabular}

$n^{*}$ indicates the number of plants in which the respective event occurred in at least one flower;

$\mathrm{n} / \mathrm{a}=$ non applicable.

transformed prior to analysis. To quantify the relationship between plant height and distance we utilized bivariate analysis using SAS (SAS Institute, Inc., 1988). Both variables were log-transformed, which made them normal. In order to examine the relationship of pollination success to all variables simultaneously, multiple regressions were performed using SAS's GLM procedure in which pollen import and/or export, and fruit production were related to plant height, spike length, number of flowers, number of leaves, distance to the nearest co-flowering conspecific, and density of co-flowering conspecifics. Non-significant variables were removed to produce a final model.

\section{Results}

Flower signals and pollinators. Flowers of D. sambucina are characterized by strong UV-absorbance (dark flower parts; Fig. 3A) with the exception of the spur entrance margins (white arrows in Fig. 3A). The yellow morph moreover shows strong reflectance between 500 and $680 \mathrm{~nm}$ (Fig. 3B). Bumblebees, cuckoo-bumblebees, and rarely Apis mellifera L. and Anthophora aestivalis Panzer visited the flowers, with the relatively large (18-22 mm long) bumblebees Bombus lapidarius and B. lucorum (Fig. 1 inset) the commonest visitors. Five bumblebees species were found to carry pollinia (Table 1). Of the three individuals of Apis mellifera and Anthophora aestivalis seen, none took-up or deposited pollinia. The bumblebees, with the exception of a B. lucorum worker noticed at the end of the flowering season, were queens, and pollinia were usually attached to their clypeus. During subsequent flower visits, small massulae from these pollinia would remain stuck on stigmas while the queens probed spurs for nectar. Bees would leave an inflorescence after having visited one to four flowers (average 1.8, $n=37$; Fig. 4). 


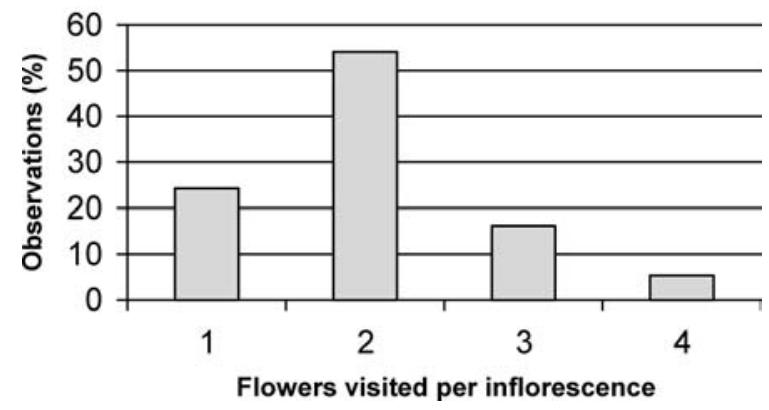

Fig. 4. Numbers of flowers visited by bumblebee queens during visits to Dactylorhiza sambucina inflorescences $(n=37)$

Pollination success. The pollination experiments confirmed that D. sambucina is non-agamospermous, incapable of automatic selfing, self-compatible, and pollinator-limited. Fruit set after experimental out-crossing was $73.3 \%$ (Table 2), compared to a natural fruit set of $19 \%$ (averaged over the two years; Table 3). On average, $49 \%$ of an individual's flowers had their pollinia removed (Table 3), while $55 \%$ of its flowers exported pollinia, received pollen, or did both (Table 3 ). The rarest event was receipt of pollen without removal of pollinia. Pollen receipt and fruit set were strongly correlated $\left(r_{\mathrm{S}}=0.77\right.$, $p<0.001$ ), and natural fruit set levels in the two years were $24 \%$ and $16 \%$ (Table 3; $n=144, n=210)$. Average plant height was $16 \mathrm{~cm}$ (Table 3 ) and did not differ among the four study locations, justifying pooling the data for subsequent analyses of relationships between height, pollinia import, export, and fruit set.

With all parameters included, only plant height $(p=0.01)$ and density of flowering conspecifics ( $p=0.03$; Fig. 1$)$ had a unique positive effect on male function. (Number of leaves per plant, number of flowers per inflorescence, and distance to the nearest flowering conspecific were so tightly correlated with each other that none made a statistically measurable unique contribution to pollen export). Female function was unrelated to height or density $(p>0.05)$. Flower position, however, had an effect on pollen export: Flowers higher on an inflorescence, which opened later in the season, had higher pollinia export proportions than flowers lower down, which opened earlier. The two-sample randomization test (Manly 1991) showed that the ratio of mean pollinia export from the upper flower positions (i.e. 10-25) to mean export from the lower flower positions (i.e. 1-9) was $70.70 \pm 20.10 \mathrm{SD}$ to $52.46 \pm 4.03 \mathrm{SD}(p=0.003)$. In contrast, the difference of mean fruit set per flower position compared over the two groups was not significant $(p=0.125)$.

\section{Discussion}

Pollination biology. Yellow- and purple-flowering populations of D. sambucina in Sweden, Austria, and France (Nilsson 1980, Vöth 1999, Gigord et al. 2001) and pure yellow populations in Germany are all predominantly pollinated by bumblebee queens. Especially important in Sweden are Bombus lapidarius (Nilsson 1980), in France B. terrestris (Gigord et al. 2001), and in Germany B. lapidarius and $B$. lucorum (this study). Bumblebees typically visit at least two flowers on the same inflorescence (Nilsson 1980; this paper), and selfing through geitonogamy is therefore possible. The honeybee has been recorded as a visitor or occasional pollinator in Sweden (Nilsson 1980), Switzerland (Reinhard et al. 1991), Austria (Vöth 1999), and Italy (Monte Baldo region; M. Kropf, pers. obs. 2000), and Nilsson (1980) noted Osmia and Halictus bees and occasionally Lepidoptera on the flowers. On the island Stora Karlsö in the Baltic, where bumblebees are extremely rare, Andrena nigroaenea (Kirby) is the main pollinator of D. sambucina (Pettersson and Nilsson 1983).

The strong UV absorbance of D. sambucina flowers (Fig. 3) increases the contrast to a UVreflecting background and therefore the probability of bee detection (Kevan et al. 1996, Vorobyev and Brandt 1997). However, due to the physical properties of bees' eyes and their neural processing of color perception, bees can only use colors as a cue for detecting objects if these appear under a large enough visual angle (Giurfa et al. 1996, Kevan et al. 1996). For an 
object of the size of an average $D$. sambucina inflorescence, a honeybee could 'read' the color information from a distance of about $51 \mathrm{~cm}$, while bumblebee queens with their much larger eyes should be able to detect the same inflorescence from further away (Land 1989, Menzel et al. 1997; A. Gumbert, pers. comm. 2004).

Pollinator behavior on rewardless flowers. In rewardless species, one expects pollina- tion success to be negatively correlated with increasing densities of flowering conspecifics because bees should learn to avoid dense patches of unrewarding individuals since they learn the location of plants rather than flowers (Menzel 1985). It has also been found that bees tend to increase the distance between flower visits and/or otherwise modify their flight path after receiving little or no reward during a

Table 4. Fruit set in natural populations of Dactylorhiza sambucina

\begin{tabular}{|c|c|c|c|c|}
\hline & No. of plants & $\begin{array}{l}\text { Mean no. } \\
\text { of flowers per } \\
\text { inflorescence }\end{array}$ & $\begin{array}{l}\text { No. of } \\
\text { inflorescences } \\
\text { with fruits }\end{array}$ & $\begin{array}{l}\text { Mean } \\
\text { fruit set }\end{array}$ \\
\hline \multicolumn{5}{|l|}{ Uppland, Sweden': } \\
\hline Purple/yellow population 1901 & 44 & 14.63 & $11(25.00 \%)$ & 3.4 \\
\hline \multicolumn{5}{|l|}{ Öland, Sweden²: } \\
\hline Purple/yellow population 1976-1979 & 708 & 12.95 & & 8.9 \\
\hline \multicolumn{5}{|l|}{ Uppland, Sweden²: } \\
\hline Purple/yellow population 1976-1979 & 158 & 16.29 & & 15.9 \\
\hline Purple plants 1977 & $217(77.78 \%)$ & 14.17 & & 48.5 \\
\hline Yellow plants 1977 & $62(22.22 \%)$ & 13.63 & & 42.9 \\
\hline Individuum-based average 1976-1979 & & & & 34.9 \\
\hline \multicolumn{5}{|l|}{ Stora Karlsö, Sweden ${ }^{3}$ : } \\
\hline Purple/yellow population 1981 & 692 & 10.26 & $76(10.98 \%)$ & 2.0 \\
\hline Purple plants 1981 & $325(46.97 \%)$ & 10.62 & $31(9.54 \%)$ & 2.0 \\
\hline Yellow plants 1981 & $367(53.03 \%)$ & 9.95 & $45(12.26 \%)$ & 2.0 \\
\hline \multicolumn{5}{|l|}{ Rhineland-Palatinate, Germany ${ }^{4}$ : } \\
\hline Pure yellow populations $1995^{\circ}$ & 17 & 13.53 & & 56.1 \\
\hline \multicolumn{5}{|l|}{ Rhineland-Palatinate, Germany ${ }^{5}$ : } \\
\hline \multicolumn{5}{|l|}{ Pure yellow populations } \\
\hline Berlachsberg 1995 & 19 & 9.21 & $14(73.68 \%)$ & 24.5 \\
\hline Berlachsberg 2003 & 15 & 7.93 & $2(13.33 \%)$ & 14.0 \\
\hline Bremroth, centre* 1995 & 72 & 8.51 & $50(69.44 \%)$ & 21.3 \\
\hline Bremroth, centre* 2003 & 20 & 6.95 & $12(60.00 \%)$ & 20.9 \\
\hline Bremroth, east* 1995 & 4 & 6.75 & $2(50.00 \%)$ & 20.0 \\
\hline Bremroth, east* 2003 & 3 & 8.33 & $2(66.67 \%)$ & 8.0 \\
\hline Bremroth, west* 1995 & 8 & 6.13 & $3(37.50 \%)$ & 8.2 \\
\hline Haarberg 1995 & 41 & 12.49 & $32(78.05 \%)$ & 30.1 \\
\hline Haarberg 2003 & 118 & 12.29 & $70(59.32 \%)$ & 16.3 \\
\hline Haarberg, nature reserve 2003 & 17 & 10.47 & $9(52.04 \%)$ & 9.0 \\
\hline Auf dem Bäder 2003 & 20 & 9.30 & $9(45.00 \%)$ & 10.2 \\
\hline Dämmerberg* 2003 & 17 & 9.18 & $11(64.71 \%)$ & 21.8 \\
\hline Average 1995 & 144 & 9.56 & $101(70.14 \%)$ & 23.5 \\
\hline Average 2003 & 210 & 10.40 & $115(54.76 \%)$ & 15.8 \\
\hline Individuum-based average 1995/2003 & 354 & 10.06 & $216(61.02 \%)$ & 18.9 \\
\hline
\end{tabular}

${ }^{1}$ Skottsberg (1907); ${ }^{2}$ Nilsson (1980); ${ }^{3}$ Pettersson and Nilsson (1983); ${ }^{4}$ Künkele and Baumann (1998);

${ }^{5}$ This study.

* All individuals in the population sampled. 
foraging bout (Heinrich 1979, Waddington and Heinrich 1981, Chittka et al. 1997). Unexpectedly, our data show that in $D$. sambucina, high densities of co-flowering conspecifics have a positive effect on pollen export. This effect may be due to the greater visual attractiveness of dense patches from a distance, an explanation that would fit with plant height (and co-varying inflorescence length) being the clearest predictors of pollination success since both also affect flower visibility from a distance. Calvo (1990) reported that larger inflorescences did not necessarily result in an increase of fruit set in three tropical selfcompatible orchid species, but these species were butterfly and fly-pollinated, insects with very different foraging behavior than bees. In the likewise self-compatible, but bumblebeepollinated rewardless Orchis spitzelii, Fritz and Nilsson (1995) found a significant positive impact of inflorescence length on pollen export and fruit set. Different from D. sambucina, however, increasing density of co-flowering conspecifics in $O$. spitzelii had a negative impact on pollen export and fruit set (Fritz and Nilsson 1995). Negative density-dependent pollination success was also observed in Orchis boryi (Gumbert and Kunze 2001). In other non-rewarding bee-pollinated orchids, however, increasing abundance of flowering conspecifics had a positive effect on fruit set, at least up to an intermediate number of flowering conspecifics (Sabat and Ackerman 1996). These seemingly contradictory results point to the importance of pollinator foraging experience in pollinator-limited plants, which may override effects of patch densities. Experiments that address the behavior of pollinators when faced with artificial rewarding and nonrewarding flowers, displayed in dense patches or intermingled with each other (and with the rewarding ones replenished consistently or only with a $50 \%$ probability) show that bumblebees visit non-rewarding flowers more often when they occur in patches (Keasar 2000), which fits with our results. These experimental results were explained as due to the bumblebees' tendency to perform runs of consecutive short-distance visits, even when not having been rewarded (Keasar 2000), with the switching decision influenced by the amount and quality of reward received at the last visited flower (e.g. Chittka et al. 1997).

Effect of flower position. It has been hypothesized that in rewardless orchids, and specifically in D. sambucina, pollination success decreases over the flowering season because bees learn to avoid rewardless flowers (Nilsson 1980, Vogel 1993). Our finding that the highest (latest-opening) flowers in an inflorescence had greater reproductive success in terms of pollen export than lower/earlier flowers would seem to contradict this hypothesis. However, a rigorous testing of the hypothesis would require data on the proportions and behavior of naïve vs. experienced bees to assess whether their seasonal change affects the pollination success of rewardless flowers. Naïve bumble workers keep emerging from nests throughout the season, but bees can learn to relate signals to rewards within one or a few visits (Menzel and Greggers 1992, Kunze and Gumbert 2001). Indeed, when Darwin (1885: p. 41-42) tested the expectation of seasonally changing fruit set in Dactylorhiza maculata (L.) Soó, albeit using only six plants, he found that the flowers in the lower halves of the spikes did not consistently have fewer capsules than those in the upper halves. Using samples of 19, 14 and 15 plants, Vallius (2000) found that in open-pollinated Finnish populations of $D$. maculata, capsule set was greatest in the middle part of the spikes in one year, while there was no difference in capsule production among different spike sections in the other two years. More experiments with individual bees of known foraging history are therefore needed to resolve what tips the balance between bees investing in learning to avoid rewardless plant individuals vs. following other behavioral programs, such as periodically (re-)sampling new and old food sources.

Effects of co-flowering plants. An important co-flowering nectar provider was the purple Lamium purpureum L.: Three bumble- 
bee species were seen pollinating both plants (Table 1), one Bombus lucorum was observed switching between Lamium and Dactylorhiza, and ten $D$. sambucina individuals had $L$. purpureum pollen on their stigmas. In colordimorphic populations of $D$. sambucina in Sweden, B. lapidarius and B. hortorum with pollinia of $D$. sambucina also visit $L$. purpureum, but also the yellow Primula veris L. and Taraxacum spec. (Nilsson 1980). The influence of bumblebee (Bombus terrestris) foraging experience with purple or yellow nectariferous flowers (such as those of Primula or Lamium) has been demonstrated experimentally in a flight cage situation by Gigord et al. (2002) and in under natural conditions by Gumbert and Kunze (2001). Both studies found that bees chose flowers depending on previous foraging experience. Given these results, abundances of Lamium purpureum, Primula veris, and other purple or yellow nectar sources in the vicinity may determine the pollination rates of purple and yellow color morphs of D. sambucina in particular populations. Notably, Jersáková et al. (in press) in color-dimorphic Czech populations found that a high abundance of Primula veris negatively affected the reproductive success of the yellow morph.

Foraging bees encounter numerous flowers and must process numerous cues (Chittka and Thomson 2001), and part of that normal range of encounters will be visits to more or less rewardless flowers (just as in Keasar's [2000] experiments, above; Thakar et al. 2003). This is because even nectar-producing flowers offer little or no reward if they have just been visited, are under water stress, or are at the wrong stage if nectar is only produced in the male or female phase of a dichogamous flower. Also, some flowers never replenish nectar, once it has been depleted (Percival 1965). Such reversible and for the bee unpredictable rewardlessness forms the backdrop of the evolutionary theatre in which exploitative pollination systems evolve (an idea developed further in Renner, in press). Faced with a constantly changing nectar market, bees need to keep exploring new flower species as old ones finish flowering, and they also occasionally need to 're-check' kinds of flowers initially found to be rewardless. As an evolutionary result, bumblebees and honeybees learn negative stimuli (unrewarding visits) more slowly than positive stimuli (Menzel and Greggers 1992), and experiments suggest that they remember mainly the positions and signals of rewarding flowers, while not storing information about numerous non-rewarding visits (Dukas and Real 1993). Bumblebees will therefore continue to explore the rewardless flowers of D. sambucina and other food-deceptive orchids (e.g. Johnson et al. 2003, and studies cited therein) whether in color-monomorphic or dimorphic populations, with visitation frequencies apparently influenced by the colors and spatial distribution of surrounding nectar sources.

Female pollination success. Fruit set levels in natural color-dimorphic D. sambucina populations in Sweden vary from 2 to $45.7 \%$, with much inter-population and inter-annual variability (Table 4). The highest fruit set so far reported is from a small monochromic yellow population about $20 \mathrm{~km}$ from our study sites (Donnersberg; Künkele and Baumann 1998). Fruit set in other European species of Orchidinae that offer no nectar (although none of them is color-dimorphic) ranges from 5.5\% in Orchis purpurea L. to $50 \%$ in Orchis papilionacea L., Dactylorhiza fuchsii (Druce) Soó, D. lapponica (Laest. ex Hartman) Soó, D. maculata (L.) Soó, and D. purpurella (T. \& T. A. Stephenson) Soó have fruit sets of $39 \%$, $16 \%, 38 \%$, and $33 \%$ (Neiland and Wilcock 1998). The 'normal' fruit set of $D$. sambucina individuals in monochromic yellow populations may indicate that the yellow morph, at least at our study sites in the RhinelandPalatinate, has high fitness due to factors unrelated to pollinator discrimination (although comparisons among widely disparate sites and years are obviously problematic). That color morph fitness may differ in particular microclimates and on certain soils has been shown in color-dimorphic (blue/ white) Linanthus parryae: Dimorphism was 
maintained not by pollinators, but by spring precipitation, with the blue morph doing better in years with low spring precipitation, the white in years with high spring precipitation (Schemske and Bierzychudek 2001). Dactylorhiza sambucina normally prefers rich soils, but at our study sites, it grows on dry, siliceous soils. Perhaps the yellow morph does better on these soils than the purple morph. Experimental plantings of the purple morph would be needed to address such possible effects of microclimate and/or microhabitat. The purple morph could also have been lost from the Rhineland Palatinate by genetic drift in small populations, but it is difficult to envision why this would not also have occurred in Sweden, France, or Austria.

The authors thank C. Schmid-Egger (Berlin) for determination of bees; A. Gumbert (Brussels), J. Kunze (Bonn), M. Quint (Mainz), and three anonymous reviewers for comments on the manuscript; R. E. Ricklefs (St. Louis) for help with statistical analyses; the nature conservancies of Koblenz and Neustadt an der Weinstraße for access permissions; and the Ministry for the Environment of the Rhineland-Palatinate for financial support to M.K.

\section{References}

Calvo R. N. (1990) Inflorescence size and fruit distribution among individuals in three orchid species. Amer. J. Bot. 77 (10): 1378-1381.

Chittka L., Gumbert A., Kunze J. (1997) Foraging dynamics of bumblebees: correlated of movements within and between plant species. Behavioral Ecology 8: 239-249.

Chittka L., Thomson. J. D. (eds.) (2001) Cognitive ecology of pollination, animal behavior and floral evolution. Cambridge University Press, Cambridge, UK.

Darwin C. (1885) The various contrivances by which orchids are fertilized by insects. J. Murray, London, UK.

Delpino F. (1874) Ulteriori osservazioni e considerazioni sulla dicogamia nel regno vegetale. Falsi nettarii e false nettaroconche. Atti della Società Italiana di Scienze Naturali e del Museo Civico di Storia Naturale (Milan) 17: 118-122.
Dukas R., Real L. A. (1993) Learning constraints and floral choice behaviour in bumblebees. Animal Behaviour 46: 637-644.

Fritz A.-L., Nilsson L. A. (1995) Reproductive success and gender variation in deceit-pollinated orchids. In: Lloyd D. G., Barrett S. C. H. (eds.) Floral biology: studies on floral evolution in animal-pollinated plants. Chapman and Hall, New York, USA, pp. 319-338.

Gigord L. D. B., Macnair M. R., Smithson A. (2001) Negative frequency-dependent selection maintains a dramatic flower color polymorphism in the rewardless orchid Dactylorhiza sambucina $(\mathrm{L}$.) Soò. Proc. Natl. Acad. Sci. (USA) 98: 6253-6255.

Gigord L. D. B., Macnair M. R., Stritesky M., Smithson A. (2002) The potential for floral mimicry in rewardless orchids: an experimental study. Proc. Roy. Soc. London, B 269: 13891395.

Giurfa M., Vorobyev M., Kevan P., Menzel R. (1996) Detection of coloured stimuli by honeybees: minimum visual angles and receptor specificc contrasts. Journal of Comparative Physiology A, 177: 699-709.

Gumbert A., Kunze J. (2001) Colour similarity to rewarding model plants affects pollination in a food deceptive orchid, Orchis boryi. Biol. J. Linn. Soc. 72: 419-433.

Hagen E. von (1994) Hummeln: bestimmen, ansiedeln, vermehren, schützen. $4^{\text {th }}$ ed. Naturbuch Verlag, Augsburg, Germany.

Heinrich B. (1979) Resource heterogeneity and patterns of movement in foraging bumblebees. Oecologia 40: 235-245.

Jersáková J., Kindlmann P., Strítesky M. (2005) Maintenance of color polymorphism in Dactylorhiza sambucina (Orchidaceae). Folia Geobot. (in press).

Johnson S. D., Peter C. I., Nilsson L. A., Agren J. (2003) Pollination success in a deceptive orchid is enhanced by co-occurring rewarding magnet plants. Ecology 84: 2919-2927.

Keasar T. (2000) The spatial distribution of nonrewarding artificial flowers affects pollinator attraction. Animal Behaviour 60: 639-646.

Kevan P., Giurfa M., Chittka L. (1996) Why are there so many and so few white flowers? Trends in Plant Science 1 (8): 280-284.

Korneck D. (1974) Xerothermvegetation in Rheinland-Pfalz und Nachbargebieten. Schriftenreihe für Vegetationskunde 7: 1-187. 
Kropf M. (1995) Vegetationskundlicher Vergleich von Standorten des Holunder-Knabenkrautes (Dactylorhiza sambucina) im Nahegebiet und der Rheinhessischen Schweiz unter Berücksichtigung von Pflege sowie Verbreitung und Gefährdung dieser Orchideenart. Fauna und Flora von Rheinland-Pfalz 8: 133-145.

Künkele S., Baumann H. (1998) Orchidaceae. In: Sebald O., Seybold S., Philippi G., Wörz A. (eds.) Die Farn- und Blütenpflanzen BadenWürttembergs, Band 8: Spezieller Teil - Juncaceae bis Orchidaceae. Ulmer Verlag, Stuttgart, Germany, pp. 286-462.

Kunze J., Gumbert A. (2001) The combined effect of color and odor in flower mimicry syndromes. Behavioral Ecology 12: 447-456.

Land M. F. (1989) Variations in the structure and design of compound eyes. In: Stavenga D. G., Hardie R. C. (eds.) Facets of vision. Springer, Berlin, Heidelberg, Germany, pp. 90-111.

Lloyd D. G. (1980) Sexual strategies in plants - III. A quantitative method for describing the gender of plants. New Zealand J. Bot. 18: 103-108.

Manly B. F. J. (1991) RT: A program for randomization testing. West Inc., 2003 Central Ave Ceyenne, WY, 82001, USA.

Menzel R. (1985) Learning in honeybees in an ecological and behavioural context. In: Hölldobler B., Lindauer M. (eds.) Experimental behavioral ecology and sociobiology. Fortschritte der Zoologie 31, Gustav Fischer Verlag, Stuttgart, Germany, pp. 55-74.

Menzel R., Greggers U. (1992) Temporal dynamics and foraging behaviour in honeybees. In: Billen J. (ed.) Biology and evolution of social insects. Leuven University Press, Leuven, Belgium, pp. 303-318.

Menzel R., Gumbert A., Kunze J., Shmida A., Vorobyev M. (1997) Pollinator's strategies in finding flowers. Israel J. Pl. Sci. 45: 141-156.

Neiland M. R. M., Wilcock C. C. (1998) Fruit set, nectar reward, and rarity in Orchidaceae. Amer. J. Bot. 85: 1657-1671.

Nilsson L. A. (1980) The pollination ecology of Dactylorhiza sambucina (Orchidaceae). Bot. Not. 133: 367-385.

Pellegrino G., Caimi D., Noce M. E., Musacchio A. (2005) Effects of local density and flower colour polymorphism on pollination and reproduction in the rewardless orchid Dactylorhiza sambucina (L.) Soò. Pl. Syst. Evol. 251: 119-129.
Percival M. S.(1965) Floral biology. Pergamon Press, Oxford, UK.

Pettersson G., Nilsson L. A. (1983) Pollinationsekologin hos Adam och Eva på Stora Karlsö. Svensk Bot. Tidskr. 77: 123-132.

Reinhard H. R., Gölz P., Peter R., Wildermuth H. (1991) Die Orchideen der Schweiz und angrenzender Gebiete. Verlag Fotorotar AG, Egg, Switzerland, $348 \mathrm{pp}$.

Renner S. S. (2005) Rewardless flowers in the angiosperms and the role of insect cognition in their evolution. In: Waser N. M., Ollerton J. (eds.) Specialization and generalization in pollination systems. University of Chicago Press, Chicago, USA, (in press).

Sabat A. M., Ackerman J. D. (1996) Fruit set in a deceptive orchid: the effect of flowering phenology, display size, and local floral abundance. Amer. J. Bot. 83: 1181-1186.

Schemske D. W., Bierzychudek P. (2001) Evolution of flower color in the desert annual Linanthus parryae: Wright revisited. Evolution 55: 12691282.

Schultz F. (1846) Flora der Pfalz. 575 pp., reprint 1971, Pirmasens, Germany.

Skottsberg C. (1907) Blommor och insekten pa Skabbholmen i Roslagen sommaren 1901. Svensk Bot. Tidskr. 1: 61-96.

Thakar J. D., Kunte K., Chauhan A. K., Watve A. V., Watve M. G. (2003) Nectarless flowers: ecological correlates and evolutionary stability. Oecologia 136: 565-570.

Vallius E. (2000) Position-dependent reproductive success of flowers in Dactylorhiza maculata (Orchidaceae). Functional Ecology 14: 573579.

Vogel S. (1993) Betrug bei Pflanzen: Die Täuschblumen. Abhandlungen der Akademie der Wissenschaften und der Literatur, Mathematisch-Naturwissenschaftliche Klasse 1993 no.1, 48 pp., Mainz, Germany.

Vorobyev M., Brandt R. (1997) How do insect pollinators discriminate colours? Israel J. Pl. Sci. 45: 103-113.

Vöth W. (1999) Lebensgeschichte und Bestäuber der Orchideen am Beispiel von Niederösterreich. Stapfia 65: 1-257.

Waddington K. D., Heinrich B. (1981) Patterns of movement and floral choice by foraging bees. In: Kamil A. C., Sargent T. D. (eds.) Foraging behaviour: ecological, ethological and psycho 
M. Kropf and S. S. Renner: Pollination success in monochromic Dactylorhiza sambucina

logical approaches. Garland STPM Press, New York, pp. 215-230.

Ziegenspeck H. (1936) Orchidaceae. In: Kirchner C. von, Loew E., Schröter C. (eds.) Lebensgeschichte der Blütenpflanzen Mitteleuropas 1 (4), 840 pp., Ulmer Verlag, Stuttgart, Germany.
Addresses of the authors: Matthias Kropf (e-mail: matthias.kropf@boku.ac.at), Institut für Botanik, BOKU - University of Natural Resources and Applied Life Sciences, Gregor Mendel Strasse 33, 1180 Vienna, Austria; Susanne S. Renner, Systematische Botanik, Ludwig-Maximilians University, Menzinger Strasse 67, 80638 Munich, Germany. 